\title{
Do we care enough? revisiting land subsidence and coastal spatial planning policy in Semarang, Indonesia
}

\author{
Rizkiana S. Hamdani, Sudharto P. Hadi', Iwan Rudiarto, Hartuti Purnaweni \\ Graduate program of environmental sciences, Diponegoro University
}

\begin{abstract}
Land subsidence is a common unsustainable pattern of land use on young sediment coasts worldwide, such as Semarang coastal area. The impact had already transformed its northeast area become permanently tidal flooded, damage in houses and streets, and economic loss. However, local government efforts are noticeably as band-aid measures, which can lead to further mismanagement in halting land subsidence. Given that, this research aimed to evaluate how the latest coastal spatial planning policy in Semarang responds to its geological hazards. This type of research is a content analysis of various spatial planning policy documents, coastal zoning plans, regional spatial planning, and strategic environmental assessment. The results show that, although land subsidence is already mentioned, no specific zoning plan or development programs were applied. Also, rather than creating more indepth law in groundwater management or other activities that exaggerate land subsidence rates, the northeast shorelines' structural measures are preferable. A key point of the result concluded that the local government should develop more strict laws in land subsidence to prevent more intense activities on land, together with vigorous law enforcement. Any structural measures should be planned and built effectively to avert more threatening problems to the regions.
\end{abstract}

Keywords. land subsidence, government response, coastal spatial planning, policy

\section{Introduction}

\subsection{Background}

Land subsidence is one of land degradation had reported occurs worldwide [1] and sounded as a sleeping disaster [2]. Cities of Indonesia which located in young sediment coasts, where urbanization and land use change massively occurs [3,4], such as Surabaya, Jakarta, and Semarang are also places where the subsidence happens [5]. It varies from natural subsidence

\footnotetext{
${ }^{*}$ Corresponding author: sudhartophadi@yahoo.com
} 
and human-induced subsidence, which dominantly caused by irresponsible land use activities [6]. Moreover, the pressure of climate related-disaster such as tidal flood has caused region's vulnerability which directly affect the livelihood sustainability of people living in coastal area [7].

Land subsidence is an irreversible environmental degradation [6]. What human can do is to measure its impact, to control the rates, and to build a proper adaptive capacity for a more resilience livelihood in most affected area. The government in some cities or countries like Japan [8], Shanghai [9], and Mexico [6] had been succeeded in controlling the rates, while others have not.

Semarang coastal area located on alluvium sediment formation, which naturally still in the process of compaction due to its young age [8]. Consequently, it experiences the most severe subsidence $[5,8,10]$. Comparing land elevation from the year 1997 to 2000, Marfai \& King [10] had concluded that the subsidence rate in Semarang is around 2-10 cm per year, with the most severe is $16.5 \mathrm{~cm}$ per year near to the shore. A decade later, Yastika et al. [8] comparing data through 2003 to 2017 and showed that the northeast area of Semarang is where the accelerated subsidence occurs, and it subsided at $24-36 \mathrm{~cm}$ per two years (see Fig. 1). Since the subsiding rates raised above $4 \mathrm{~cm}$ per year, the average rates of natural subsidence, it classified as rapid subsidence and indicated an anthropogenic stressor contribution [5].

Researchers so far concluded that groundwater extraction by industrial areas plays a leading role in exaggerating land subsidence rates [5,10-12]. It happened as consequences from the inability of region's water supplier company to fulfill the city's need [13-15]. Besides, well digging has not being restricted due to the same problem, which enables domestic water consumers to add groundwater withdrawal amount. Then, the human-induced categorized land subsidence is what is happening in Semarang coastal area.

There are sinking houses in the northern area of Semarang due to land subsidence [11]. In the north east area, land owners had lost their assets due to the permanent flooding, while others have adaptation expenses to regularly elevate their floor or upgrade the house structures against frequent floods [16,17]. The seawater intrusion had also threatening freshwater supply [11]. The contribution of subsiding land and the rising seawater level globally could be worsening tidal flood [18]. It lessens the environment's capacity to deal with climate change-related hazards [7,19]. Consequently, the risk faced by coastal communities is spiking [20] while the vulnerability of the region is increased [21].

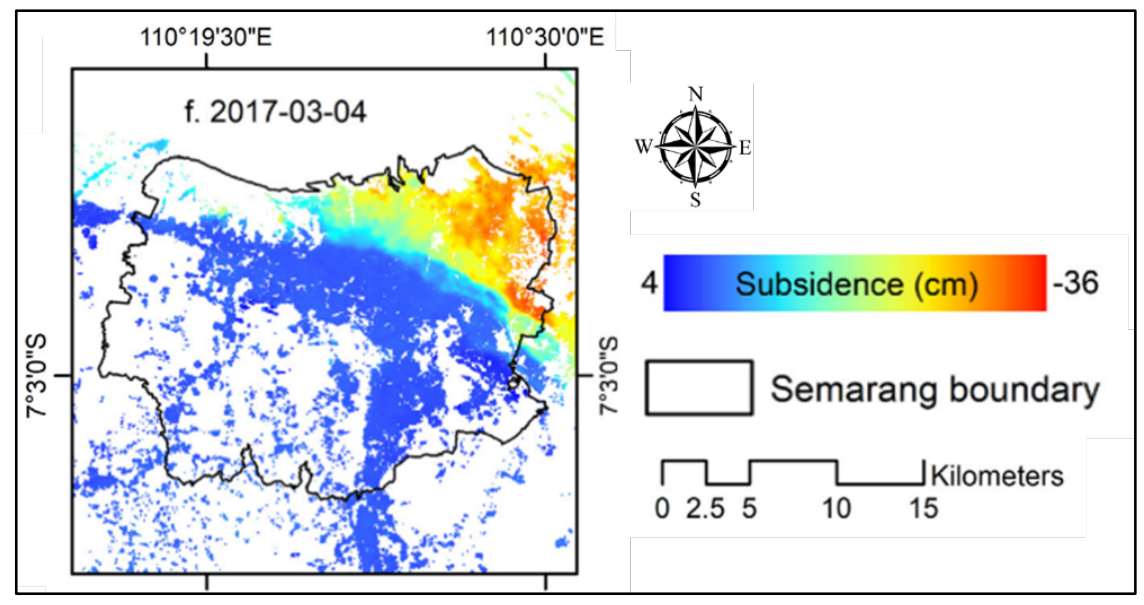

Fig. 1. Land subsidence map of Semarang City [8] 
Spatial planning was also considered in discussing this problem. As the carrying capacity exceeded due to subsiding land, current and future city planning still considering economically profitable activities rather than considering environmental sustainability $[10,11,19]$. Land use policy that hardly restricts specific activities in subsided area also contributed in worsening the rates.

Scientists had also considered land subsidence as a major geological hazard that risking livelihood and sustainability [9]. While the measures to effectively halt the problem remains in the exploratory stage. This hazard powerlessly guided policy into achieving harmony between human activity and the stress put on the ecosystem. It happened at a slow rate, so the impact may not be as threatening as any other disaster. Also, it becomes rarely considered as an environmental hazard [6]. Thus, it was the only reasonable thing that could rationalize why land subsidence is hardly affecting the planning policy.

In Indonesia there is a challenging policy regime. The coastal area faces two different spatial planning regimes, which managed in two different stakeholders, the planning board agency and marine and fisheries ministry. Moreover, city itself in the local governance level is hardly affects what has already been mandated by the central government. Currently, the groundwater management's responsibility is moved from local government to the regional (provincial) government.

This article tried to portray how the land subsidence itself being understood and operationalized in spatial planning documents by investigating what things have been and have not been done and agreed in current policy regimes. It is an effort to capture how does the regime challenges specific on this sinking issue and understanding current policy-related challenges before decluttering ideas for controlling subsidence rate because any projects and development in the city should be in line with what already mentioned in policy.

\subsection{Land subsidence in the lens of carrying capacity}

Land subsidence defined as a vertical movement of the upper soil layer caused by imbalance pressure in the lower layer of the soil [1]. One of the main culprits is the withdrawal of natural resources. Groundwater, oil, and gas extracted to fulfill human needs, both commercial and domestic. As the recharge capacity was not meet balance with it, the void pores started to collapse; thus, subsidence happened as the consequences. As illustrated in Fig. 2, the other activities, such as civil structures and building loads, were aggravating subsidence rates by adding too many loads to the degraded soil layer. It related with urbanization on a land which intensifies population densities, development of built environment, and demand on freshwater [3].

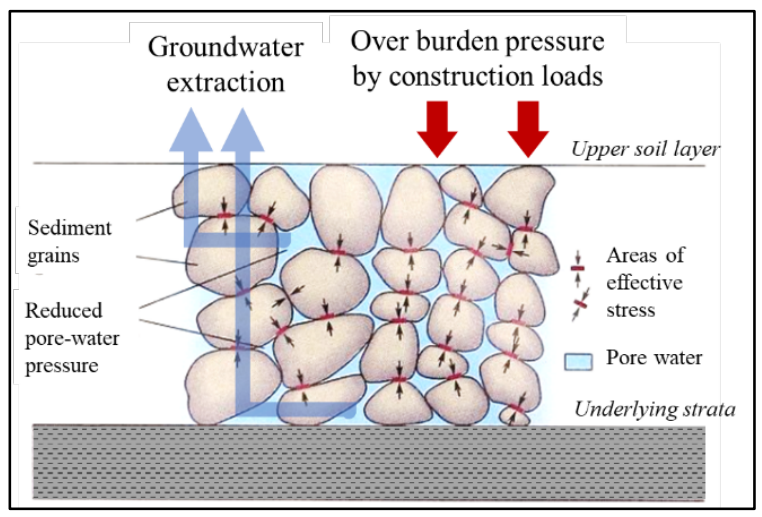

Fig. 2. Underground pore pressure reduction which causing subsidence or sediment compactions [6] 
Despite anthropogenic stressors, subsidence is also a part of the natural consolidation process that occurs on young of alluvium soil or sediment. Pipkin et al. [6] classified subsidence into two major categories. If tectonic or volcanic activities caused the subsidence, it regarded as a natural subsidence. Natural consolidation that happened on the young age of soil layer is also considered the same [22].

Land subsidence later defined as one of the environmental hazards caused by ecological overshoot [6]. Derived from mechanics perspective, land carrying capacity is maximum loads that could be given into an acre of land [23]. It related to its geological capability [6,24]. When it comes to subsidence, the overshoot is when the surface soil cannot hold the loads while the pressure balance underneath the surface is collapsing, as illustrated in the figure above.

Carrying capacity in the urban region uses the lens of human carrying capacity. It differentiates from, the ecological or biological. Thomas Malthus firstly defined human carrying capacity as the maximum amount of human life on land [25]. On the other side, it seems like forcing a war to maintain the population at a certain level [26]. It also influences the concept of measuring carrying capacity, which counted total land demand based on population growth [27]. Its origin considering carrying capacity as a static state, but in cities, it should be understood as dynamic. Because it does not only considering natural endowment to ensure human sustainability, it also consists of complexity in many human-made aspects such as economics, public participation, or even politics [25].

\subsection{Operationalizing carrying capacity in spatial planning policy to halt land subsidence in Indonesia}

Spatial planning developed as a tool to ensure the harmony between human needs and the sustainability of the ecosystem. It offers land use management, enabling the government or landowners to plot human activities. The harmony itself could only be seen if that "plotting" mechanism is considering how the natural world works. Briefly, it should consider the environmental carrying capacity whenever they wanted to delineate the spatial pattern.

The spatial planning policy of Indonesia is regulated in Constitution Law Number 26/2007. Article 6 paragraph (1) point a stated that spatial planning should consider the physical condition of the region that prone to disaster. Spatial planning is differed in two, the general and the detailed. The general plan, the spatial pattern or land use plan and spatial structure plan policy, is made based on governmental authority level; national, provincial, and city. Besides, the detailed spatial planning is based on strategic issues, such as special economic zone, or archipelagic area. The mandate to make spatial planning for every city is derived into Agrarian and Spatial Planning Ministerial Regulation Number 1/2018. Stated in article 7 paragraph 1 point $\mathrm{j}$, disaster risk reduction should also be analyzed in the early process of planning, which is data analysis, before creating concept of the spatial plan. On the other side, spatial planning for marine and coastal areas is regulated in different law, which is Constitution number 27/2007. In addition, the products of both regulations should be intertwined each.

Through Constitution Law Number 32/2009, Indonesian government states that principles of sustainable development should be integrated into development, planning, program, and policy. The Strategic Environmental Assessment (SEA) or Kajian Lingkungan Hidup Strategis (KLHS) used to ensure implementability of sustainable development parallel with spatial planning policy. Consequently, this law mandates that the coastal spatial planning policy documents and products should incorporate any recommendations mentioned in SEA regarding the region's carrying capacity and carrying capability. It also helps the regional or local government in implementing environmental preservation towards sustainable development [26]. 
Carrying capacity analysis in the process of policy planning in Indonesia should be stipulated in SEA. The result of the analysis is used as a sword to evaluate every program stated in spatial and development planning. If the carrying capacity is exceeded, SEA should give recommendations in halting those issues, and the planning documents should synchronize it into a better plan that would give no harm to the environment. Strictly stated in Law Number 32/2009 that any activity contributed in causing the exceeded carrying capacity should be stopped or revised.

\section{Methods}

A qualitative method focused on document screening, skimming, and understanding is called content analysis or literature review. It used to assess operationalization of theoretical concept into policies [28], defining conceptual framework of solving the specific problem [29], understanding current issues and confirming other sources of information [30], and assessing integration of SEA and spatial planning [31].

Conducting qualitative research to clarify measures and effort in halting land subsidence through spatial planning policy is still scarcely found. It dominated by quantitative research on monitoring and describing how threatening is subsidence occurs in the city $[5,8,10,22,32]$. The literature review related to this issue had been conducted in order to create recap and develop ideas [33], and not give a step into analyzing current policies and management. Assessment of spatial planning responses and role to environmental hazards itself had also conducted using a quantitative overlay method with content analysis as a supporting method to develop discussion $[18,19]$. Consequently, this article tried to fill that niche to address the problem into more contextual spatial planning policy, which publicly agreed through words, law, and report.

This research is conducted in five steps, adapted from [29]. The first step is identifying main research problem by reviewing previous studies and reports. It was the most critical step to choose the specific questions and lists of curiosities that would be answered by this research. As what have been described above, the research questions are:

(1) "how important is land subsidence in planning policy?" to analyze the government's awareness and attention with the issues;

(2) "what are measures enacted to halt causes and impacts of land subsidence?" used to identify the effectivity of projects and planning stipulated in the policy regarding the causes and problems mentioned above; and

(3) "how is the integration and coherence between multilevel and multisectoral planning policy?" used to understand the commitment in implementing sustainable development in coastal area of Semarang.

The second step is identifying spatial planning policy that applicable in the coastal area in Semarang. In this case, the result is a list of four documents from multilevel governance and multisectoral (land and coastal area). The third step is catching up with the latest progress of spatial planning policy which currently being in progress on revision. In Indonesia, stated in Law Number 32/2009 that any kind of revision in public policy should be acquainted with strategic environmental assessment. This step enacted two other documents, which is for the revision of city's spatial planning and province's zoning plan for coastal areas (see Table 1).

The fourth step is to understand how vital land subsidence is in the spatial planning policy documents. It extracted from the frequencies of specific keywords related to land subsidence (such as: "amblesan tanah", "penurunan muka tanah", "penurunan permukaan tanah", and "penurunan tanah) mentioned in the document [28]. In this step, the whole word-specific containing sentences collected and then analyzed in the next step. Before starting to analyze the selected content, another process in the fourth step is to open possibilities in any other 
words to address land subsidence. It was conducted by collecting sentences mentioned about tidal flood and groundwater management.

The fifth step is analyzing the selected content. The conformity and difference are all recorded and discussed in this research. In this step, we also conducted interviews with experts to enhance our discussion. Thus, this is a critical step to take a conclusion and answering the rest research questions.

Table 1. List of sources

\begin{tabular}{|c|c|c|c|c|}
\hline No & Document Name & Code* & Level & Type* \\
\hline 1 & $\begin{array}{l}\text { Regional Law of Semarang City Government Number } \\
14 / 2011 \text { about Spatial planning of Semarang City } 2011- \\
2031\end{array}$ & $\begin{array}{l}\text { SP } \\
\text { Semarang }\end{array}$ & City/Local & $\mathrm{SP}$ \\
\hline 2 & $\begin{array}{l}\text { Regional Law of Jawa Tengah Province Number } \\
06 / 2010 \text { about Spatial Planning of Jawa Tengah } \\
\text { Regency 2009-2029 }\end{array}$ & $\begin{array}{l}\text { SP Jawa } \\
\text { Tengah }\end{array}$ & Province/Regional & SP \\
\hline 3 & $\begin{array}{l}\text { Regional Law of Jawa Tengah Province Number } \\
13 / 2018 \text { about Zoning Plan of Coastal Areas and Small } \\
\text { Islands } 2018-2038\end{array}$ & $\begin{array}{l}\text { ZP Jawa } \\
\text { Tengah }\end{array}$ & Province/Regional & $\begin{array}{l}\text { SP } \\
\text { (Zoning } \\
\text { Plan/ZP) }\end{array}$ \\
\hline 4 & $\begin{array}{l}\text { Strategic Environmental Assessment of Revision of } \\
\text { Regional Law of Semarang City Government Number } \\
\text { 14/2011 about Spatial planning of Semarang City 2011- } \\
2031\end{array}$ & $\begin{array}{l}\text { SEA } \\
\text { Semarang }\end{array}$ & City/Local & SEA \\
\hline 5 & $\begin{array}{l}\text { Strategic Environmental Assessment of Revision of } \\
\text { Regional Law of Jawa Tengah Province Number } \\
13 / 2018 \text { about Zoning Plan of Coastal Areas and Small } \\
\text { Islands 2018-2038 }\end{array}$ & $\begin{array}{l}\text { SEA } \\
\text { Jawa } \\
\text { Tengah }\end{array}$ & Province/Regional & SEA \\
\hline 6 & $\begin{array}{l}\text { Governmental Law of Indonesian Republic Number } \\
26 / 2008 \text { about National Spatial Planning }\end{array}$ & $\begin{array}{l}\text { SP } \\
\text { Indonesia }\end{array}$ & National/National & SP \\
\hline
\end{tabular}

\section{Results}

\subsection{Revisiting the sleeping disaster in Semarang city's planning policy}

This part would try to identify the first research question in this paper, understanding the importance of land subsidence in the coastal spatial planning policy of Semarang. It had already academically shouted that land subsidence is currently happening in Semarang, and more severe occurs in the coastal area $[5,10,18,21,22,34,35]$. Meanwhile, it found that the term "land subsidence" was rarely mentioned in the selected documents. There are only found twice in the Spatial Planning of Semarang City. It said that land subsidence is considered as region's limitations towards certain development program and one of the tidal flood causes.

To be relieved, land subsidence is highly mentioned in SEA of Semarang's Spatial Planning. There were 100 sentences mentioning land subsidence using various vocabularies. It also told that most of city's planning projects are on land subsidence-prone area. It could be portrayed that the government had the awareness of the hazards. It's frequent mentioning also indicates that land subsidence had been considered as one of limitations in the city's development. It also indicates that the SEA had been treating this geological hazard with spatial planning program as a strategic issue, which should be incorporated in spatial planning as mandated in Constitutional Law number 32/2009.

On the other side, it turns out quite disappointing when the result found in SP is contrast. In all the SP reviewed in this research, the term related to land subsidence mentioned less than ten times, two times to be exact. It showed that although there is awareness towards the hazards, it does not imply that the government had considered the urgency to halt it. Consequently, it is hard to find such specific action to halt the rates or mitigate the impacts 
stipulated in the documents. The result resonates with what had been discussed by Saputra $[2,36]$. Using three indicators: (i) awareness, (ii) urgency, and (iii) action, he found that government response had only had the high score in awareness. It had not considered land subsidence as an urgent hazard or, moreover, take an action.

Table 2. Word frequencies

\begin{tabular}{|c|c|c|c|c|c|c|}
\hline \multirow{3}{*}{ Vocabularies } & \multicolumn{2}{|c|}{$\begin{array}{c}\text { Strategic Environmental } \\
\text { Assessment (SEA) }\end{array}$} & \multicolumn{3}{|c|}{ Spatial Planning } & \multirow{3}{*}{ Total } \\
\hline & Local & Regional & Local & Regional & National & \\
\hline & $\begin{array}{l}\text { SEA } \\
\text { Semarang }\end{array}$ & $\begin{array}{l}\text { SEA Jawa } \\
\text { Tengah }\end{array}$ & $\begin{array}{l}\text { SP } \\
\text { Semarang }\end{array}$ & $\begin{array}{l}\text { SP Jawa Tengah, } \\
\text { ZP Jawa Tengah }\end{array}$ & $\begin{array}{l}\text { SP } \\
\text { Indonesia }\end{array}$ & \\
\hline $\begin{array}{l}\text { Land subsidence: } \\
\text { amblesan tanah, } \\
\text { penurunan muka } \\
\text { tanah, penurunan } \\
\text { permukaan tanah, } \\
\text { and penurunan } \\
\text { tanah }\end{array}$ & 100 & 6 & 2 & 0 & 0 & 108 \\
\hline $\begin{array}{l}\text { Tidal flood: rob, } \\
\text { banjir pasang and } \\
\text { banjir rob }\end{array}$ & 60 & 9 & 9 & 0 & 0 & 78 \\
\hline
\end{tabular}

Comparing it to the other hydrometeorological hazards, tidal flood, the difference had just raised the attention. There were mentions amount discrepancy between "tidal flood" and "land subsidence". In total, both SEA and SP, Tidal flood was only stipulated 78 times, whilst land subsidence is 108 times (see more on Table 2). While in the spatial planning policy itself, it was the contrary, tidal flood mentioned four times more than land subsidence. Most of the term-containing sentences are related to what and how should planning do in the zone where vulnerably endangered by tidal flood. City-level planning of Semarang had a specialized zone for tidal flood-prone zone as one of natural disaster-prone zone. It implies that there was also a specific zoning regulation for tidal flood prone area but there was not any stipulated specific zone for land subsidence prone areas, as shown in Fig. 3. This is important because the zoning plan is based on disaster-prone classification areas, which could influence the development or activities that exaggerating environmental exposures [17].

The spatial plan was also explicitly detailing the measures to halt the flooded area. Specific cases such as Port of Tanjung Emas, which functioned as an economically strategic zone, also got the plans to reduce impact and affected areas. In contrast, land subsidence has no literal mention in stipulating how it should be halted, except for describing what the problem encountered by the cities are. The same pattern also found in what Jakarta Sea Wall Master Plan. Although it is a more technical spatial planning document, Octavianti \& Charles [37] found that although the frequencies of land subsidence problems mentioned in the document had reached 50 times, there were no specific measures to halt it.

It was interesting when there are different vocabularies to express tidal flooding problems. It is widely known that flood comes out in different understanding based on its causes. The two most common are tidal and pluvial floods. Unfortunately, the term "tidal flood" is found only in the local level of planning. In the regional and national planning, the more general term "flood" used to describe areas which both prone to tidal and pluvial flooding.

In consequences, there were no specific planning and regulation related to tidal flooding in macro-level planning. It could lead to the misconception of flooding caused by sea-level dynamics towards its spatial planning and development policy. On the other side, development and planning projects implemented in a city not always derived from local governments will because the national and regional level government also give inputs and influence on that. This issue would be more be discussed in point 3.3.

As what have found in [28] that Indonesian spatial planning regulation has not had its specific term to describe and mention "resilience" in Indonesian Language, the same thing 
happened into these two issues, tidal flood and land subsidence. For the land subsidence, besides writes the English term, there were four different phrases used in planning documents "amblesan tanah", "penurunan muka tanah", "penurunan permukaan tanah, and "penurunan tanah". For the tidal flood, the terms used are "rob", "banjir pasang" and "banjir $r o b^{\prime}$. More advance, tidal flood is often associated with the pluvial flood with the term "rob dan banjir" or even more being considered as disaster "bencana rob" (tidal flood disaster).

It captured that spatial planning in Semarang, from local to the national level, had more consider tidal flood as an urgent hazard than land subsidence, as shown in differences in word frequencies and the classification of disaster-prone zones. In contrast, the increasing rates of subsidence could worsen the tidal flood. Rather than halt the subsidence as causes, the government prioritized the floods as one of the subsidence's impacts. In these findings, we confirmed the understanding of "band-aid" [38] or underachieved [4] policy respond.

\subsection{Government measures in dealing with land subsidence}

A development project's effectiveness is defined as how it could react and respond straight to the root causes of the problem. As what has written as the second research question, this part would discuss more in how measures taken by the government in halting causes and impacts of land subsidence regarding how it responded to what is happening in Semarang.

As discussed in the previous part, land subsidence hardly defined as a specific problem, hazard, or disaster that needed a specific list of actions and regulations. It implies that no literal sentences are stipulating the strategies used by the government to halt land subsidence. We would discuss it regarding human-induced problems that are exaggerating subsidence rates in Semarang; groundwater extraction and building loads.

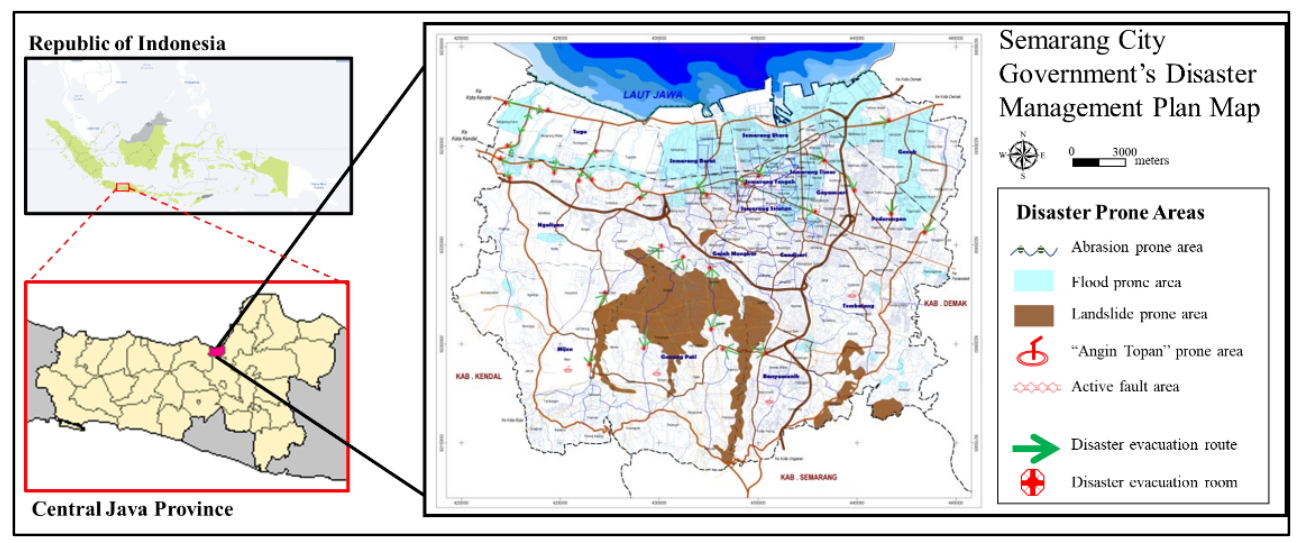

Fig. 3. Stipulated disaster-prone area in Semarang City's Spatial Plan 2011-2031

Groundwater extraction believed as the main problem causing land subsidence in Semarang $[10,13,22,33]$. Measures taken to oversee this is stipulated in SP Semarang article 35, that in nine districts of Semarang, the groundwater extraction should be restricted. They are: (i) Kecamatan Tugu, (ii) Kecamatan Semarang Barat, (iii) Kecamatan Semarang Utara, (iv) Kecamatan Semarang Tengah, (v) Kecamatan Semarang Selatan, (vi) Kecamatan Semarang Timur, (vii) Kecamatan Genuk, (viii) Kecamatan Pedurungan, and (ix) Kecamatan Gayamsari. Those areas are experiencing land subsidence. The SP itself does not have detailed information on how the implementation of its restriction. On the other side, constitutional law number 23/2014 about Regional Government had mandated that authority of groundwater controlling is on the regional level of governance, which in this case is the 
provincial government. Thus, coordination and good cooperation between those levels of governance are essential to ensure the restriction meets its aim.

Freshwater provisioning becomes another point stipulated in SP Kota Semarang. In article 33-point $b$, there would be the development of freshwater source alternatives that came from rainwater harvesting and pipelines. Ideas of reusing water from treating industrial wastewater for domestic uses had shouted by [13] and had been proposed to the local government but had not mentioned in the SP. Reducing groundwater extraction had been mandated to increase city's resiliency [39]. Moreover, it stated that groundwater usage also counted as part of freshwater supply for the city.

As the impact of land subsidence, Semarang government has a more detailed plan in halting tidal flood. There were six specific articles in SP Semarang containing control and management plan for tidal flooding. As the consequences of delineating tidal flood-prone areas, zoning regulation had been stipulated, such as: implementing adaptive housing, and it was permissible to build structural measures. In detail, technical engineering allowed are dikes, sea wall, retention pond, and runoff canal (stipulated in article 118 point 6 ). Hadi [40] reported that there was already a polder system implemented to control excessive runoff whenever the flood comes.

Another measure related to coastal hazards is the sea wall as a civil work measure. A vast structure planned to prevent tidal flooding. Regarding groundwater extraction, The Sea Wall has a plan to add a retention pond, which could function as an alternative freshwater for both domestic and commercial uses. A similar plan had mentioned in Water As Leverage plan developed by Semarang's government through 100 Resilient Cities [14].

It is confirmed later through interviews with planners and academicians, that this plan would have no direct contribution to land subsidence. It could give direct positive feedback for the affected areas, but not in the long term [40]. Joko, part of the planning consultant for this project, said that its primary goal is to halt tidal flooding. He continued that land subsidence is a complex issue regarding disposition, sedimentation, erosion, etc, which hardly affected only by the sea-wall project.

"The effectivity of sea-wall project in halting tidal flood and land subsidence would only

be reached if only being supported by stopping groundwater extraction, minimizing

building loads, stopping sand mining, and conserving mangrove forests or greenbelt minimizing in shorelines"

Sutrisno Anggoro, Professor in coastal management (Universitas Diponegoro)

It stated in the quotation above that the giant sea wall itself could not be a stand-alone solution in increasing the carrying capacity of the coastal area to maintain its sustainability. Urban activists in Semarang, through the local legal aid organization, also said that this megaproject could harm a society because there would be two divided ecosystems "inside" the wall and "outside" the wall. Unfortunately, coastal communities as people in Tambaklorok District would be in the outside area, which would get negative impacts. This changing ecosystem also confirmed by Anggoro, which had an opinion that there would be ecological succession "inside" the sea wall. They also said that the measures to halt the ecological impact itself had not addressed in the project's environmental impact assessment.

Mila Karmilah, the lecturer of urban and regional planning from Universitas Sultan Agung, Semarang, showed her doubt on this project. Presented in Launching of Position Paper regarding this project by Lembaga Bantuan Hukum (Legal Aid Services) Semarang, she said that this project was only be mentioned in SP Semarang and have not been integrated into other SP (the provincial and national level) [40]. It gives her confusion and doubt about who initiated this project and its true intentions. Is it truly to enhance the coastal community's resilience or the contrary. She continues that this project could worsen coastal socio-system because it hardly meets the equity for impacted people, especially the "outside" ones. It resonates the urge to develop bottom-up adaptation plan said by [41]. 
While the local actors are debating its urgency, the project had already become national strategic programs as the Presidential Regulation Number 56/2018 about the Second Amendment on the Acceleration of the Implementation of National Strategic Project released. The response continues afterward, all the spatial planning (local, regional, and national) did a significant revision to incorporate this project. Both in regional and local SEA analysis showed that structural measures in northeastern Semarang would contribute to increasing the carrying capacity of the coastal areas. Although it's exact contribution is not detailed explicitly in those two SEAs, the development plan is to continue progressing.

The spatial planning policy applied in Semarang prefers to use the word "restriction" which have a more similar meaning with "limitation" rather than using the word "stopping" to regulate the groundwater extraction. Learning from countries that had succeeded in stabilizing land subsidence rates, such as Shanghai [9], stopping groundwater is the most crucial issue to be strictly regulated. Regarding this fact, it could be preliminary concluded that Semarang had not started its strict law enforcement in subsurface exploitation activities.

As building loads aggravating subsidence rates, planning policy had not stated building restriction in the subsided area. Moreover, confirming [19], plotted planned development lies in subsiding areas. The recommendation of policy changing, stipulated in SEA, uses a generalized term "using structural measures" to ensure the development would not spike the rates. The unstandardized structural measures itself could increase the possibility of changing sides from solution into causing more complex problems.

\subsection{Multilevel and multisectoral planning in coastal management}

The implementation of sustainable management in coastal areas of Semarang undoubtedly needed cross-sectoral coordination and cooperation. It showed in two regimes of planning, land, and sea, which comes out into two different planning documents. Coherence between those two documents in Semarang coastal areas could be portrayed by looking at how the tidal flood is considered in developing useful measures where the sea wall plan comes out. As the land subsidence hardly captured by this plan, the land-sea integration in its coastal management remains questionable.

Dialogue mechanism applied to both SEA and SP is a conceptual paradigm that builds the understanding of all the goodness in coastal spatial planning (see Fig. ). It also showed in the selected documents how the problems and its solving plan are cross-referenced. When reading the SEA of SP, it mentioned the result stated in SEA of ZP, vice versa. Another thing to consider more is SEA functioned as an obtuse sword because the recommendation mentioned to make development and land subsidence in harmony ended up in generalized solutions without any strict movement. Despite this, the SEA itself had no power to enforce the incorporations, and it indirectly impacted the land use regulations. As what have known in the literature, strategic environmental assessment is a tool used to integrate environmental considerations into the planning process and policy $[29,42]$. Also, in the Indonesian Republic Constitution Number 32/2009 about Environmental Management and Protection mandated in Article 17 that whenever the carrying capacity identified exceeded, the spatial planning programs should rely on SEA results and recommendations. While in practice, it is powerless [43]. Revised coastal spatial planning could fill in the niche. However, it needed far more time to understand since the process of coordination itself would not meet an end. 


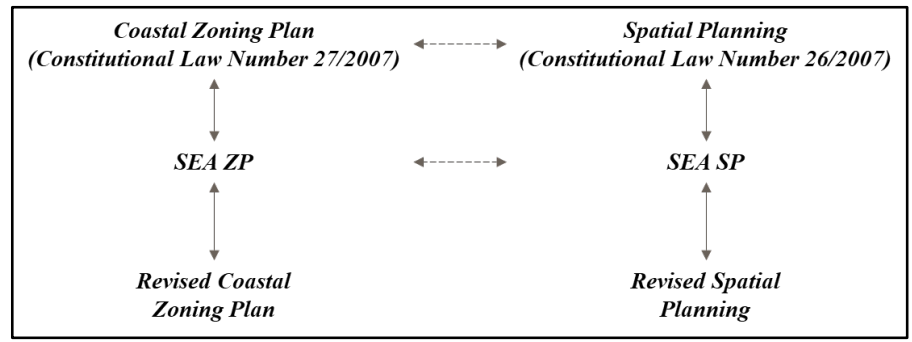

Fig. 4. Dialogue between spatial planning documents (multisectoral planning)

Land subsidence had not explicitly mentioned in a higher level of planning. Besides, it could aggravate eco-anxiety because the project initiated by the higher-level government would not always meet the local ground. As the toll road or giant sea wall project, higherlevel planning recommended this project because it could increase ecological sustainability and increasing its connectivity. In contrast, the lower level of planning, it doubted it by mentioning that that plan lies on a subsiding land. This inharmony should have the attention of all government levels to not misjudge and mis plan about a thing which is essential to save the lives of the cities and its citizen and not further the distinctions between the ideal concept of spatial planning and its implementation.

The multilevel planning in managing groundwater extraction activities is also hardly portrayed. Because at the lower level, it had mentioned the restriction, while the authority is on the higher level of planning. Also, land use planning and zoning regulation have not portrayed the importance of saving subsurface resources.

\section{Conclusions}

It can be concluded that the government of the Indonesian Republic, Central Java Province, and Semarang had been aware of land subsidence and its impact but not consider it as an urgent environmental hazard that should be managed. It only stated in the SEA, and not being fully integrated to the SP. The planning process itself needed to make a shift to give more concern in ecological and environmental sustainability. Shift paradigm in including land subsidence in disaster-prone areas classification is also be needed. The impacts of rising rates could be worsened if the vigorous law enforcement of land use and management policies is not there.

Also, evaluating measures that have been taken by the government, it focused on tidal flood as an impact rather than controlling building loads and groundwater extraction as the causes. It could only give direct positive feedback for the affected areas, but not give such an enormous impact for the long term. The multisector and multilevel planning in coastal spatial planning also become a challenge in developing sustainable development in coasts. The interaction between different spatial planning levels already proves a quite good connection and coherence, while the multisector remains needed improvement. The coherence between SEA and SP should be enhanced to ensure the development would not harm the environment.

\section{References}

1. D. H. Carlson, C. C. Plummer, L. Hammerslet, Physical Geology: Earth Revealed, 9th Editio (McGraw-Hill, 2010)

2. E. Saputra, Land Subsidence As A Sleeping Disaster Case studies from Indonesia (Utrecht University, 2020)

3. I. Rudiarto, W. Handayani, J. S. Setyono, A Regional Perspective on Urbanization and 
Climate-Related Disasters in the Northern Coastal Region of Central Java, Indonesia, in Land 7, 34 (2018) doi:10.3390/land7010034

4. H. Purnaweni, Coastal Abrasion in Sayung District Demak Regency: A Call for A More Responsive Policy, in in in Int. Conf. Indones. Soc. Polit. Enq. 1, (2016)

5. E. Chaussard, F. Amelung, H. Abidin, S. H. Hong, Sinking cities in Indonesia: ALOS PALSAR detects rapid subsidence due to groundwater and gas extraction, in Remote Sens. Environ. 128, 150-161 (Elsevier Inc., 2013) doi:10.1016/j.rse.2012.10.015

6. B. Pipkin, D. Trent, R. Hazlett, P. Bierman, Susidence and Collapse, in in in Geol. Environ., 7th ed. (Cengage Learnings, 2008)

7. I. Rudiarto, W. Handayani, H. B. Wijaya, T. D. Insani, Land resource availability and climate change disasters in the rural coastal of Central Java - Indonesia, in IOP Conf. Ser. Earth Environ. Sci. 202, 012029 (2018) doi:10.1088/1755-1315/202/1/012029

8. P. E. Yastika, N. Shimizu, H. Z. Abidin, Monitoring of long-term land subsidence from 2003 to 2017 in coastal area of Semarang, Indonesia by SBAS DInSAR analyses using Envisat-ASAR, ALOS-PALSAR, and Sentinel-1A SAR data, in Adv. Sp. Res. 63, 17191736 (2019) doi:10.1016/j.asr.2018.11.008

9. X. C. He, T. L. Yang, S. L. Shen, Y. S. Xu, A. Arulrajah, Land subsidence control zone and policy for the environmental protection of Shanghai, in Int. J. Environ. Res. Public Heal. 16, 1-13 (2019) doi:10.3390/ijerph16152729

10. M. A. Marfai, L. King, Monitoring land subsidence in Semarang, Indonesia, in Environ. Geol. 53, 651-659 (2007) doi:10.1007/s00254-007-0680-3

11. ACCCRN, ISET, Mercy Corps, CCROM Southeast Asia and Pacific IPB, Urban and Regional Development Institute, Laporan Akhir Kajian Kerentanan dan Adaptasi terhadap Perubahan Iklim Kota Semarang, 2010

12. T. D. N. Le, Climate change adaptation in coastal cities of developing countries: characterizing types of vulnerability and adaptation options, in Mitig. Adapt. Strateg. Glob. Chang. (Springer, 2019) doi:10.1007/s11027-019-09888-z

13. W. Beek, B. Letitre, H. Hadiyanto, S. Sudarno, Alternatives to groundwater abstraction as a measure to stop land subsidence: a case study of Semarang, Indonesia, in E3S Web Conf. 125, Hadiyanto, Budi Warsito, and Maryono, Eds., 01003 (Semarang, 2019) doi:10.1051/e3sconf/201912501003

14. One Architecture \& Urbanism, Kota Kita, Deltares, Yayasan Lahan Basah (Wetlands International), Sherwood Design Engineer, Grobak Hysteria, The Nature Conservancy, Atelier Ten, Universitas Diponegoro, et al., Water as Leverage for Resilient Cities Asia: Volume II Concept Design Proposals, 2019

15. DLH Kota Semarang, Kajian Lingkungan Hidup Strategis (KLHS) Revisi Rencana Tata Ruang Wilayah (RTRW) Kota Semarang, Kota Semarang, 2017

16. I. Rudiarto, H. Rengganis, A. Sarasadi, E. Caesar, The Effectiveness of Strategy Adaptations on Tidal Flood in The Coastal Areas of Sayung, Demak, Central Java, Indonesia, in IOP Conf. Ser. Earth Environ. Sci. 448, 012090 (2020) doi:10.1088/17551315/448/1/012090

17. I. Rudiarto, D. Pamungkas, Spatial Exposure and Livelihood Vulnerability to ClimateRelated Disasters in The North Coast of Tegal City, Indonesia, in Int. Rev. Spat. Plan. an Sustain. Dev. 8, 34-53 (2020) doi:10.14246/irspsd.8.3

18. I. Buchori, A. Sugiri, M. Mussadun, D. Wadley, Y. Liu, A. Pramitasari, I. T. D. Pamungkas, A predictive model to assess spatial planning in addressing hydrometeorological hazards: A case study of Semarang City, Indonesia, in Int. J. Disaster Risk Reduct. 27, 415-426 (Elsevier Ltd, 2018) doi:10.1016/j.ijdrr.2017.11.003

19. D. S. A. Suroso, T. Firman, The role of spatial planning in reducing exposure towards impacts of global sea level rise case study: Northern coast of Java, Indonesia, in Ocean Coast. Manag. 153, 84-97 (Elsevier, 2018) doi:10.1016/j.ocecoaman.2017.12.007 
20. L. Nurhidayah, A. McIlgorm, Coastal adaptation laws and the social justice of policies to address sea level rise: An Indonesian insight, in Ocean Coast. Manag. 171, 11-18 (Elsevier, 2019) doi:10.1016/j.ocecoaman.2019.01.011

21. Husnayaen, A. B. Rimba, T. Osawa, I. N. S. Parwata, A. R. As-syakur, F. Kasim, I. A. Astarini, Physical assessment of coastal vulnerability under enhanced land subsidence in Semarang, Indonesia, using multi-sensor satellite data, in Adv. Sp. Res. 61, 2159-2179 (COSPAR, 2018) doi:10.1016/j.asr.2018.01.026

22. H. Z. Abidin, H. Andreas, I. Gumilar, T. P. Sidiq, Y. Fukuda, Land subsidence in coastal city of Semarang (Indonesia): characteristics, impacts and causes, in Geomatics, Nat. Hazards Risk 4, 226-240 (2013) doi:10.1080/19475705.2012.692336

23. J.-X. Wang, B. Feng, L.-S. Hu, Y.-Q. Tang, X. Yan, H. Wang, J. Liu, Application of geoenvironmental capacity of ground buildings in urban planning Application of geoenvironmental capacity of ground buildings in urban planning, in Environ. Earth Sci. 69, 93-102 (2013) doi:10.1007/s12665-012-1937-z

24. S. P. Hadi, Bunga Rampai Manajemen Lingkungan (Yogyakarta, 2014)

25. Y. Wei, C. Huang, J. Li, L. Xie, An Evaluation Model for Urban Carrying Capacity: A Case Study of China's Mega-Cities, in Habitat Int. 53, 87-96 (Elsevier Ltd, 2016) doi:10.1016/j.habitatint.2015.10.025

26. E. Budi, K. Dewi, M. Erli, B. Ulfa, A. Ghozali, H. K. D. M. Erli, B. U. Aulia, A. Ghozali, E. B. Santoso, et al., Concept of Carrying Capacity: Challenges in Spatial Planning (Case Study of East Java Province, Indonesia), in Procedia - Soc. Behav. Sci. 135, 130135 (Elsevier B.V., 2014) doi:10.1016/j.sbspro.2014.07.336

27. Hariyanto, S. P. Hadi, I. Buchori, The Population Growth and Carrying Capacity in Semarang City, in E3S Web Conf. 31, 1-4 (2018) doi:10.1051/e3sconf/20183107010

28. W. Handayani, M. R. Fisher, I. Rudiarto, J. Sih Setyono, D. Foley, Operationalizing resilience: A content analysis of flood disaster planning in two coastal cities in Central Java, Indonesia, in Int. J. Disaster Risk Reduct. 35, 101073 (Elsevier Ltd, 2019) doi:10.1016/j.ijdrr.2019.101073

29. E. Oliveira, S. Tobias, A. M. Hersperger, Can strategic spatial planning contribute to land degradation reduction in urban regions? State of the art and future research, in Sustain. 10 (2018) doi:10.3390/su10040949

30. S. P. Hadi, H. Purnaweni, B. Prabawani, R. S. Hamdani, Community Movement for Sustainable Use of Natural Resources: Case study of North Kendeng Mountain Area, Central Java, Indonesia, in IOP Conf. Ser. Earth Environ. Sci. 448, 012069 (2020) doi:10.1088/1755-1315/448/1/012069

31. D. Rozas-vásquez, C. Fürst, D. Geneletti, O. Almendra, Land Use Policy Integration of ecosystem services in strategic environmental assessment across spatial planning scales, in Land Use Pol. 71, 303-310 (Elsevier, 2018) doi:10.1016/j.landusepol.2017.12.015

32. M. A. Marfai, L. King, Tidal inundation mapping under enhanced land subsidence in Semarang, Central Java Indonesia, in Nat. Hazards 44, 93-109 (2008) doi:10.1007/s11069-007-9144-z

33. D. Sarah, E. Soebowo, Land subsidence threats and its management in the North Coast of Java, in IOP Conf. Ser. Earth Environ. Sci. 118 (2018) doi:10.1088/1755$1315 / 118 / 1 / 012042$

34. F. Kuehn, D. Albiol, G. Cooksley, J. Duro, J. Granda, S. Haas, A. Hoffmann-Rothe, D. Murdohardono, Detection of land subsidence in Semarang, Indonesia, using stable points network (SPN) technique, in Environ. Earth Sci. 60, 909-921 (2010) doi:10.1007/s12665009-0227-x

35. H. Andreas, H. Zainal Abidin, D. Pradipta, Di. Anggreni Sarsito, I. Gumilar, Insight look the subsidence impact to infrastructures in Jakarta and Semarang area; Key for adaptation and mitigation, in in in MATEC Web Conf. 147, (2018) 
doi:10.1051/matecconf/201814708001

36. E. Saputra, T. Hartmann, A. Zoomers, T. Spit, Fighting the Ignorance: Public Authorities' and Land Users' Responses to Land Subsidence in Indonesia, in Am. J. Clim. Chang. 4, 1-21 (2017) doi:10.4236/ajcc.2017.61001

37. T. Octavianti, K. Charles, De- and Re-politicisation of Water Security as Examined Through the Lens of the Hydrosocial Cycle: The Case of Jakarta's Sea Wall Plan, in Water Altern. 12, 1017-1037 (2019)

38. RVO Netherlands, Water as Leverage for Resilience Cities, in in in Int. Semin. Resilient City, (2019)

39. Semarang City Government, Resilient Semarang: Moving Together towards a Resilient Semarang, First edit (Semarang City Government, Semarang, 2016)

40. S. P. Hadi, In Search for Sustainable Coastal Management: A Case Study of Semarang, Indonesia, in IOP Conf. Ser. Earth Environ. Sci. 55, 012054 (2017) doi:10.1088/1755$1315 / 55 / 1 / 012054$

41. H. Purnaweni, Kismartini, S. P. Hadi, I. Soraya, Coastal Community Group for Coastal Resilient in Timbulsloko Village, Sayung, Demak Regency, Indonesia, in E3S Web Conf. 31, Hadiyanto, Sudarno, and Maryono, Eds., $09009 \quad$ (2018) doi:10.1051/e3sconf/20183109009

42. E. B. Santoso, K. D. M. Erli H, B. U. Aulia, A. Ghozali, Concept of Carrying Capacity: Challenges in Spatial Planning (Case Study of East Java Province, Indonesia), in Procedia - Soc. Behav. Sci. 135, 130-135 (Elsevier B.V., 2014) doi:10.1016/j.sbspro.2014.07.336

43. S. P. Hadi, H. Purnaweni, B. Prabawani, The Powerless of Strategic Environmental Assessment (SEA): A Case Studies of North Kendeng Mountain Area, Central Java, Indonesia, in E3S Web Conf. 125, 9-11 (2019) doi:10.1051/e3sconf/201912502014 